\title{
Visual Memory Test based on Snodgrass Pictures (VMT-SP): a New Neuropsychological Measure of Visual Memory on Children with Learning Disabilities*
}

\section{Prueba de Memoria Visual basada en imágenes de Snodgrass (VMT. $\mathrm{SP})$ : una nueva medida neuropsicológica de memoria visual para niños con Dificultades de Aprendizaje}

\author{
J. Angela Muñoz-Machicao ${ }^{a}$ \\ Universidad de Granada, España \\ ORCID: http://orcid.org/0000-0002-6891-3469 \\ Manuel Fernández-Alcántara \\ Universidad de Alicante, España \\ ORCID: http://orcid.org/0000-0002-3481-8156 \\ Cayetana Correa-Delgado \\ Hospital Universitario San Cecilio, España \\ ORCID: http://orcid.org/0000-0003-4279-6548 \\ Amanda Rocío González-Ramírez \\ Fundación Pública 12 Andaluza para la Investigación, \\ España \\ ORCID: http://orcid.org/0000-0003-4588-6717 \\ Miguel Pérez García \\ Universidad de Granada, España \\ ORCID: http://orcid.org/0000-0003-4775-7556 \\ Carolina Laynez-Rubio \\ Hospital Universitario San Cecilio, España \\ ORCID: http://orcid.org/0000-0003-2447-1723
}

\footnotetext{
${ }^{a}$ Correspondence author. Email:

angela.munozma@gmail.com
}

How to cite: Muñoz-Machicao, J. A., FernándezAlcántara, M., Correa-Delgado, C., GonzálezRamírez, A. R., Pérez, M., \& Laynez-Rubio, C. (2019). Visual memory test based on Snodgrass pictures (VMT-SP): a new neuropsychological measure of visual memory on children with learning disabilities. Universitas Psychologica, 18(2), 1-15. https:// doi.org/10.11144/Javeriana.upsy18-2.vmtb

\section{ABSTRACT}

Introduction: Visual memory can be defined as the ability to recall visual images in the form of objects events or words. Previous neuropsychological research on Learning Disabilities (LD) involving visual memory has been focused particularly on children who present nonverbal LD, and their scholar underachievement. Objective: This study aims to develop a visual memory test using recognisable objects and to determine their normative values and validity in a population of children with LD and in a control group. Methods and procedures: A total of 330 children participated in this study (7-14 years), 190 suffered of some kind of LD and 140 did not have any diagnosis. Visual Memory was assessed using a test (VMT-SP) based on Snodgrass Pictures (Snodgrass \& Vanderwart, 1980) composed of a short-term, long-term and a recognition assessment. Rey Complex Figure Test (RCFT) and Hooper Visual Organisation Test (HVOT) were used to assess validity. Results: Short-term, long-term recall and long- 
term recognition differed significantly between the LD children and the control group. Moreover, the scores were influenced by the age of the children (with a higher percentage of correct answers being given by the older children), gender, habitat and mother's level of education. Finally, the test results were associated with other measures of visual memory. Conclusions: VMT-SP is a new clinical tool for assessing visual memory. We present evidence of its concurrent validity and applicability in the evaluation of children with LD.

Keywords

Visual Memory; Learning Disabilities; Neuropsychology; Children.

\section{RESUMEN}

Introducción: La memoria visual se define como la habilidad para recordar imágenes visuales en forma de objetos eventos o palabras. Investigaciones previas en niños con dificultades de aprendizaje se han centrado principalmente en la relación entre la memoria visual y el fracaso escolar. Objetivos: Desarrollar una prueba de memoria visual usando imágenes de objetos familiares y determinar sus valores normativos y evidencias de validez en una población de niños que padecen dificultades de aprendizaje además de un grupo control. Métodos y procedimientos: Un total de 330 niños participaron en este estudio (7-14 años), 190 padecían algún tipo de dificultad de aprendizaje y 140 no tenían ningún diagnóstico. La memoria visual fue evaluada usado una prueba (VMTSP) basada en las figuras de Snodgrass que evaluó la memoria a corto, largo plazo y el reconocimiento. También se utilizó la figura compleja de Rey y el Hooper Visual Organisation Test. Resultados: Los resultados de las tres variables del VMP-SP difirieron significativamente en niños con dificultades de aprendizaje del grupo control. Las puntuaciones fueron influenciadas por la edad (con un mayor porcentaje de respuestas correctas proporcionadas por los niños de más edad), el género, el nivel educativo de la madre y el hábitat. Finalmente se encontró una correlación moderada con otras pruebas de memoria visual. Conclusiones: VMT-SP es una nueva herramienta clínica para la evaluación de la memoria visual. Se ha presentado evidencia de su validez concurrente y su aplicabilidad en la evaluación de niños que padecen dificultades de aprendizaje.

\section{Palabras clave}

Memoria Visual; Dificultades de Aprendizaje; Neuropsicología; Niños.

Visual memory can be defined as the ability to recall visual images in the form of objects, events or words. It is part of a network of interactive systems that enables us to register and store information to make it available for subsequent recovery (Soprano, 2003). Researchers have divided this type of memory into three main subsystems: Visual Sensory Memory, Visual Short-Term Memory and Visual Long-Term Memory (Luck \& Hollingworth, 2008). Despite its importance, there is still no clear and general consensus on the relationship between visual memory and other visual aspects such as visuospatial organization (Eng, Chen \& Jiang, 2005; Pissella \& Mattingley, 2004). Albeit both capabilities lie within the visuospatial domain, they do not have a direct interaction despite their evident interrelation. For example, recent studies identified how visual working memory performance can be facilitated by Gestalt principles such as connectedness, similarity, and spatial proximity (Peterson \& Berryhill, 2013).

On the other hand, attention plays a central role in visual working memory, having a reciprocal influence (Carlisle \& Kristjánsson, 2018). Souza and Oberauer (2017) indicated how looking to multiple targets across the visual filed depends on visual attention, while visual working memory depends mostly on central attention. Moreover, some authors propose that visual working memory shares a standard capacity limit with visual attention (Chun, 2011; Franconeri, Alvarez, \& Cavanagh, 2013).

Recent studies in children with learning disabilities (LD) have shown that academic underachievement is not always due to deficiencies in general intelligence, but may be associated with neuropsychological alterations, among which are the different types of memory (Alloway, Banner, \& Smith, 2010; Brandenburg et al., 2015; Liebel \& Nelson, 2017; Maehler \& Schuchardt, 2016). Although academic performance has more frequently been associated with verbal memory, in recent years the significance of visual memory and visuospatial functions for certain types of LD has also been noted (Klesczewski et al., 2015).

Neuropsychological research on LD involving visual memory have been focused mainly on children who present nonverbal LD, one of the most important of which is visuospatial impairment (Mammarella, Lucangeli, \& Cornoldi, 2010; Garcia, Mammarella, Tripodi, \& Cornoldi, 2014), in which a lower performance is 
obtained in tests relying on visuospatial memory than in those requiring verbal abilities (Lindell \& Rasmusen, 2005; Narimoto, Matsura, Takezawa, Mitsuhashi \& Hiratani, 2013; Willis, Goldbart, \& Stansfield, 2014). These impairments are especially prevalent when the information must be activated and processed in order to perform complex visual tests (Mammarella \& Pazzaglia, 2010), and also have repercussions on mathematical activities such as solving arithmetic and geometric problems (Brankaer, Ghesquiere, \& De Smedt, 2014; Bull, Espy, \& Wiebe, 2008; Mammarella, Giofre, Ferrara, \& Cornoldi, 2013; Passolunghi, 2006; SemrudClikeman, Walkowiak, Wilkinson, \& Butcher, 2010) as well as a great impact reading disorders (Werpup-Stuewe \& Petermann, 2015).

In children with verbal LD, studies have revealed the extension of impairments towards nonverbal domains, caused mainly by a lack of strategies for processing information. These difficulties are apparent in tests dependent on visual information, in the slowness of their execution and in greater difficulty in remembering visual content than spatial locations (Garcia, Mammarella, Pancera, Galera, \& Cornoldi, 2015; Montgomery, 2000; Seigneuric, Ehrlich, Oakhill, \& Yuill, 2000).

Finally, regarding children with attentional LD, studies of children diagnosed with attention deficit and hyperactivity disorders (ADHD) reported average performance in simple visual tests (Galindo et al., 2001), having poorer results for tasks that are reliant on visual memory (Rhodes, Coghill, \& Matthews, 2004; Schuchardt \& Mähler, 2016), especially as concerns to those activities that require the retention of abstract patterns and the recognition of previously-learned spatial locations (Shang $\&$ Gau, 2011). This behavior pattern seems to persist during adolescence and is related to the subjects' level of executive function competence (Müller et al., 2007).

Much remains to be discovered regarding the evaluation of memory in children (Soprano, 2003; Willis, Goldbart, \& Stansfield, 2014). This is particularly true for visual memory, which has been less often studied than verbal memory
(Brown, Roth, Saykin, \& Beverly-Gibson, 2007). Following Price (2009), the tests employed to assess visual memory can be grouped according to the materials used:

(i) Tests based on manipulative objects: for example, Corsi blocks (Corsi, 1973), which are used to evaluate the subject's ability to retain the identity of objects located in a specific order and space. This test corresponds to the domain of sequential visuospatial working memory.

(ii) Tests based on figures that are not associated with object representations. One of the best known is Rey's complex figure, which is used to measure the domains of visuoperceptual organization and visuospatial memory. All tests based on this type of content are more closely related to purely visuospatial abilities. Researchers are currently seeking to measure visual and spatial domains separately and to design a test that requires a combination of these two domains.

(iii) Tests based on recognizable objects: these tests seem to depend on the episodic buffer of which they could be a measure for visual memory (Price, 2009), and require the subject to make a connection between semantic and episodic memory of objects and words (Cuetos, Ellis \& Alvarez, 1999; Snodgrass \& Vanderwart, 1980; Wyatt, Conners \& Carr, 1998). This is the type of tests where very few studies have been conducted or normalized sets of figures proposed for evaluating this type of memory, either in the normal population or in subjects with LD (Pérez \& Navalón, 2003).

Nevertheless, there is a large amount of research that has used recognizable objects. Snodgrass and Vanderwart (1980) using a total of 290 everyday images, studied factors such as familiarity and naming by a cohort of native English speakers. Based on these data, they developed a database of pictures that have been used in a wide range of memory studies both with adults and children. For example, Cuetos, Ellis, and Alvarez (1999) used the Snodgrass and Vanderwart pictures to determine object familiarity and rated the age of acquisition of visual memory; subsequently, Reales, Ballesteros and García (2002) identified the thresholds for 
the 260 screen-fragmented words corresponding to the total set of Snodgrass and Vanderwart pictures. The development of children's cognitive functions and the sensitivity of "match" versus "no-match" responses to visual, semantic and lexical predictors have also been assessed using this stimulus (Stadthagen-González, Damian, Pérez, Bowers, \& Marín, 2009; Wang, Chen, $\&$ Zhu, 2014). Although the Snodgrass pictures have proved to be useful for measuring visual memory skills to the best of our knowledge, no specific tool using these images has been designed, nor has its validity and accessibility has been tested on an English or Spanish-speaking clinical population of children with LD.

With these considerations in mind, in this study we have the following aims: (i) to design a visual memory test based on Snodgrass and Vanderwart (1980) and Cuetos et al. (1999) studies, using recognizable objects, and to determine normative values for a population of children with some form of LD, and also for a control group; (ii) to determine the validity of this test regarding other visual tests and taking into account other sociodemographic variables. At the outset, we hypothesized that (i) the children diagnosed with LD would remember fewer pictures and would present more errors than the children in the control group; (ii) the visual memory score obtained would be positively correlated with other measures of visual memory and visual perception (taking into account other sociodemographic variables, such as the child's gender, age and habitat).

\section{Methods}

\section{Participants}

A total of 330 children participated in this study. Their ages ranged from 7 to 14 years with a mean age of 10.83 years $(S D=2.26), 196$ were male (59.4\%) and the most abundant subgroup came from an urban habitat ( $n=146,44 \%)$, with the others coming from semi-urban $(n=105,31.8 \%)$ and rural $(n=73,22.1 \%)$ areas (six children, $2.1 \%$, had missing values on this variable). Some of the participant's relevant characteristics are shown in Table 1.

\section{Table 1}

Sociodemographic characteristics of Learning Disability and Control group

\begin{tabular}{|c|c|c|c|c|}
\hline & \multicolumn{2}{|c|}{$\begin{array}{c}\text { Learning } \\
\text { Disability (LD) } \\
\text { Group } \\
\end{array}$} & \multicolumn{2}{|c|}{$\begin{array}{c}\text { Control Group } \\
\text { (CG) }\end{array}$} \\
\hline & $\begin{array}{c}\text { Mean } \\
\text { or } N\end{array}$ & $\begin{array}{c}\text { SD or } \\
\%\end{array}$ & $\begin{array}{c}\text { Mean } \\
\text { or } \mathbf{N}\end{array}$ & $\begin{array}{c}\text { SD or } \\
\%\end{array}$ \\
\hline Age (months) & 124.6 & 27.9 & $124.9 \pm$ & 25.8 \\
\hline \multicolumn{5}{|l|}{ Sex } \\
\hline Male & 133 & $70 \%$ & 63 & $45 \%$ \\
\hline Female & 57 & $30 \%$ & 77 & $55 \%$ \\
\hline \multicolumn{5}{|l|}{ Habitat } \\
\hline Rural & 49 & $26.6 \%$ & 24 & $17.2 \%$ \\
\hline Semi-rural & 67 & $36.4 \%$ & 38 & $27.1 \%$ \\
\hline Urban & 68 & $37 \%$ & 78 & $55.7 \%$ \\
\hline \multicolumn{5}{|c|}{ Mother's educational level } \\
\hline Primary & 98 & $71 \%$ & 72 & $56.7 \%$ \\
\hline Secondary & 35 & $25.4 \%$ & 39 & $30.7 \%$ \\
\hline Univeristy & 5 & $3.6 \%$ & 16 & $12.6 \%$ \\
\hline \multicolumn{5}{|l|}{ Diagnostic } \\
\hline Attentional ADHD & 60 & $31.6 \%$ & -- & $\cdots$ \\
\hline Hyperactive ADHD & 60 & $31.6 \%$ & -- & $\cdots$ \\
\hline SLI & 16 & $8.4 \%$ & --- & $\cdots$ \\
\hline Literacy disorder & 37 & $19.5 \%$ & -- & - \\
\hline ASD & 17 & $8.9 \%$ & --- & $\cdots$ \\
\hline KBIT IQ & 93.77 & \pm 13.98 & $104.54 \pm$ & 11.43 \\
\hline RCFT - Copy & 22.58 & 8.61 & $27.58 \pm$ & 7.66 \\
\hline RCFT - Recall & 13.29 & 7.21 & $17.01 \pm$ & 7.44 \\
\hline Hooper Test & 20.50 & 4.39 & $21.87 \pm$ & 3.91 \\
\hline
\end{tabular}

NotesKBIT- Kaufman Brief Intelligence Test; IQ - Intellectual Quotient, SLI- Specific language impairment; ASD - Autism spectrum disorder, RFCT- Rey Complex Figure Test, SD - Standard Deviation.

The Learning Disability Group (LD) was composed of 190 children aged from 7 to 14 years, referred from the neuropediatric clinic of the San Cecilio Hospital in Granada (Spain) where they were being treated for LD. These children were evaluated by a clinical psychologist at the hospital's pediatrics department to assess whether they met the conditions to be included in the study. The inclusion criteria in the LD group were the presence of continued LD that were not explained by any neuropsychological or cognitive deficit. In the LD group, a total of $120(63.2 \%)$ children had a diagnosis of ADHD, while 53 (27.9\%) had verbal LD and 17 (8.9\%) had non-verbal LD.

The Control Group (CG) was composed of 140 children aged between 7 and 14 years, recruited from various schools in the province of Granada. The inclusion criteria for this 
group were having a proper school performance (average or over the mean grades) during several years and not having had to retake any study year. A clinical psychologist and a neuropediatrician also assessed them in order to discard any type of $\mathrm{LD}$, emotional or psychiatric psychopathology.

The exclusion criteria for both groups were: (i) moderate-severe cognitive or neurological deficit assessed by Kaufman Brief Intelligence Test ( ${ }^{\text {nd }}$ Edition) and (ii) severe emotional or psychopathological alteration reported by children's mother using the Child Behavior Checklist for ages 6-18 (Achenbach \& Rescorla, 2001).

\section{Instruments}

\section{Visual Memory Test based on Snodgrass Pictures} VMT-SP

To facilitate recognition, the pictures were selected based on the degree of identification of the word represented. Reales, Ballesteros and García (2002) calculated the identification threshold for each word in the full set of Snodgrass and Vanderwart pictures in Spanish and found a set of 83 readily identifiable words. In the present study, 50 words were randomly selected from this set and the corresponding pictures employed in the final version of the test. The mean threshold values and the IDs are shown in Table 2. The pictures used in the test are available as Supplementary Material. Following previous studies conducted to assess visual memory (Cuetos et al., 1999; Luck, \& Hollingworth, 2008), the current test (VMT-SP) was divided into three different parts: (i) Shortterm assessment, (ii) Long-term assessment and (iii) Recognition assessment.

1. Short Term Recall: A sheet of A3 paper with 20 pictures (marked with an asterisk in Table 2) was presented to the participants, who were told to look carefully at all of the pictures on the page during 20 seconds.
Researcher Instructions: Look carefully at these pictures, pay proper attention to them because you will have to name them later

After the time has passed, the page was taken away. Immediately after the children were asked to name all the items from the A3 sheet they could recall.

Researcher Instructions: Which items do you remember?

Score: The researchers recorded all of the children's answers and awarded a score of 1 for each picture named that matched one on the first sheet, otherwise zero.

2. Long Term Recall: 20 minutes later, the child was instructed to name all of the pictures recalled from the first A3 sheet

Researcher Instructions: Do you recall the sheet with pictures on it I've shown you previously? Well now name all of the items you remember from it, please.

Score: The evaluator recorded the answers given and scored correct and incorrect responses in the same way as before.

3. Long Term Cued Recognition: Immediately after, he/she was shown an A4 sheet that included previous A3 elements as well as distractor new pictures were added (see Table 2), and was asked to point out with an $\mathrm{X}$ the ones they remembered from the first A3 sheet, there was no time limitation for this part.

Researcher Instructions: Now watch carefully all the pictures, and mark with an $\mathrm{X}$ the ones you remember that were on the original sheet. 
Score: The answers were scored likewise the previous tests.

Table 2

Normative data for the different images used in creating the VMT-SP, from Reales et al. (2002)

\begin{tabular}{|c|c|c|c|c|c|c|c|}
\hline Name & ID & $\begin{array}{c}\text { Threshold } \\
\text { Spanish }\end{array}$ & Range & Name & ID & $\begin{array}{c}\text { Threshold } \\
\text { Spanish }\end{array}$ & Range \\
\hline Bee & 23 & 4.85 & 5 & Caterpilar & 50 & 2.9 & 8 \\
\hline Hand & 115 & 1.85 & 2 & Window* & 257 & 5 & 2 \\
\hline Wheel ${ }^{*}$ & 254 & 4.4 & 6 & Ladder & 131 & 5.2 & 6 \\
\hline Goat & 107 & 4.4 & 4 & Shoe* & 204 & 2.75 & 5 \\
\hline Windmill* & 256 & 4.15 & 5 & Leg* & 134 & 6.25 & 5 \\
\hline Cloud $^{*}$ & 62 & 2.65 & 6 & Star & 217 & 5.8 & 2 \\
\hline Cat & 49 & 3.7 & 3 & Bell & 25 & 4.05 & 6 \\
\hline Book* & 30 & 5.05 & 8 & Bird* & 28 & 2.15 & 8 \\
\hline Hair* & 114 & 3.35 & 3 & Necklace & 153 & 5.45 & 4 \\
\hline Axe & 12 & 6.85 & 5 & Chair & 53 & 3.95 & 4 \\
\hline Arm & 7 & 5.55 & 5 & Key* & 128 & 3.25 & 6 \\
\hline Hammer* & 114 & 3.35 & 7 & Rabbit & 182 & 2.1 & 4 \\
\hline Chicken & 55 & 5.2 & 5 & Train* & 240 & 4.75 & 6 \\
\hline Church* & 57 & 5.75 & 7 & Needle & 154 & 4.95 & 6 \\
\hline Lemon & 135 & 3.55 & 5 & Nose & 155 & 4.2 & 5 \\
\hline Bow & 33 & 4 & 4 & Hat ${ }^{*}$ & 118 & 2.75 & 4 \\
\hline Telephone* & 227 & 3.05 & 6 & Bottle & 32 & 4.05 & 4 \\
\hline Tie & 232 & 4.4 & 5 & Chain & 52 & 5.8 & 6 \\
\hline Toe & 235 & 4.35 & 8 & Horse & 121 & 3.8 & 4 \\
\hline Accordion & 1 & 4.4 & 7 & Table* & 226 & 4.45 & 5 \\
\hline Leaf* & 133 & 5.1 & 5 & Ruler* & 192 & 5.5 & 5 \\
\hline Gun & 112 & 3.5 & 6 & House & 122 & 3.4 & 7 \\
\hline Pocketbook & 178 & 3.75 & 5 & Piano* & 171 & 3.45 & 7 \\
\hline Car & 47 & 3.65 & 3 & Coat & 64 & 5.65 & 5 \\
\hline Lamp & 132 & 4.05 & 6 & Sun* & 222 & 3.05 & 5 \\
\hline
\end{tabular}

Notes * Elements presented in the first test (A3) for later recall

If at any time during the assessment the child asked, "What is this?" about a picture or he named any given item, no concrete answer was given. Instead, the researcher replied, "Whatever you think". This was done because semantic memory works differently from visual memory, and we wished to avoid prompting an answer. If the child insisted on naming the picture incorrectly, but in a recognizable way, this was scored as a correct response, because the aim of this test was to assess visual memory, not semantic fluency; thus, what was important was the remembering or recognition, not the naming of the object (see Table 2).

\section{Rey Complex Figure Test (RCFT)}

This test consists of copying and then reproducing by memory a figure using memory skills (Rey, 1980). The test is applied to children aged from 4 to 15 years, as well as to adults diagnosed with a cognitive deficiency. Performance of the test is scored on the overall outcome of the copy produced (global perceptive structure and copy type) and on the number of details correctly copied (precision or copy quality). There is no time limitation for the copy or the reproducing part. The reproduction part is administered 20 minutes after the first part. This test is widely used on toddlers in order to assess their intellectual perceptive-motor development, as well as attention, immediate visual memory, and intellectual operation speed. It has also been used for clinical examinations with children and adults, in areas such as spatial structure, agnosia and apraxia (Tirado-Durán, 2006). The scores shown in the tables are expressed on a direct score of the overall quality level of both copy and memory.

\section{Hooper Visual Organisation Test (HVOT)}

This test evaluates neurologic deterioration by examining visual integration and is relatively free of situational effects (Hooper, 1983). It is applied to children aged 5 years and older, who are asked to identify 30 objects represented by puzzle drawings. The results are presented as $\mathrm{T}$ scores and cut-off points, with one point awarded for each object correctly identified, and half a point for those named in a general way. In the present study, the raw scores were used, because scales do not exist for Spanish samples.

Kaufman Brief Intelligence Test (2004) Second Edition (KBIT-2)

KBIT-2 is a brief, individually administered measure of verbal (vocabulary subtest) and nonverbal (matrix subtest) intelligence. This test is designed to provide a brief, individualized format for measuring verbal and nonverbal intelligence in children and adults. The age range of administration goes from 4-90 years old and takes between 15-30 minutes to administer. It can be applied in an extensive broad of settings, including clinical, educational, vocational, and research. KBIT-2 can be used as a screener for intellectual abilities and identification of children who are at-risk for academic problems (Bain \& 
Jaspers, 2010). This test generates three scores: Verbal, Non-Verbal and an overall IQ composite.

\section{Procedure}

In the LD group, after application of the inclusion and exclusion criteria, an initial interview was held with the parents and the child. In this interview, the parents were informed orally and written of the purpose and content of the study, and their signed informed consent was requested. The evaluation was conducted using a set of neuropsychological tests, including those selected for this study. The order of the tests was always the same for all participants. Two neuropsychologists conducted the tests in two 90-minute sessions in a well-lit, quiet room at the San Cecilio Clinical Hospital (Granada).

The control group was composed of children with no LD, recruited from schools in the catchment area of the hospital. In this case, the same neuropsychologists as the LD group carried out the tests at the schools, using the same procedure (in two 90-minute sessions, in a quiet room, and following the same order of application). The teachers at each school informed the parents in written form, about the project, and those who agreed to participate in the study gave their informed consent.

This study was approved by the Clinical Research Ethical Committee for the province of Granada (Reference: PI-10/02735). Before participation, written informed consent was obtained from each parent or guardian. All were explicitly informed as to the voluntary nature of the study and the possibility of abandoning it at any time without having to give any explanation.

\section{Data analysis}

The data were analyzed using IBM-SPSS, version 21. The level of statistical significance for this study was $p<0.05$. For the $L D$ and the $\mathrm{CG}$, the mean values and standard deviations were calculated for the correct and incorrect responses for each variable included in the visual memory test. To obtain normative values, four ranges of age were chosen, according to their similar neuropsychological development (see recent examples such as Burneo-Garcés et al., 2019; Mous et al., 2017): 7-8 years, 9-10 years, 11-12 years and 13-14 years. A series of ANOVAS and non-parametric comparisons for independent samples (Mann-Witney test) were conducted to determine the differences between the groups. Bivariate non-parametric correlations (Spearman's Rho) were calculated to identify relationships between the visual memory test and other measures of visual memory and visual perception. Finally, to study the role of sociodemographic variables backward linear regression analysis were performed for each of the three dimensions of the visual memory tests, with the subject's age, gender $(0=$ Boy, $1=$ Girl), family habitat (which was recoded into three dummy variables: (a) $0=$ rest of conditions, $1=$ rural; (b), $0=$ rest of conditions, $1=$ semi-urban; $0=$ rest of conditions, 1 $=$ urban) and educational level of the mother (also recoded in three dummy variables: (a) $0=$ rest of conditions, $1=$ primary, (b) $0=$ rest of conditions, $1=$ high school, and (c), $0=$ rest of conditions, $1=$ university) as independent variables. In order to increase the statistical power in the regression analysis, the entire sample was used.

\section{Results}

Objective 1: Normative values for the VMT-SP in the LD and control groups

Mean values for the variables of the VMTSP, depending on the age and the group (LD and CG) are shown in Table 3. A series of ANOVAS were performed, in each of which the dependent variable was the score for the dimension of the VMT-SP and the independent variable was the group (Table 4). Statistically significant differences were found for the short-term recall, long-term recall and longterm recognition assessments. The numbers of errors in the first and third variable were also statistically different between the groups, with 
the children in the LD group achieving lower scores in the three main variables, recognizing fewer objects and making more errors.

A series of ANOVAs were carried out to study the influence of age on the performance of the test, using the four age groups as the independent variable. The Bonferroni correction was employed to study post-hoc comparisons. Results of the ANOVAs are shown in Table 3. For short-term recall, post-hoc analysis showed that the scores achieved by the children aged 7-8 years differed from those of the children aged 10-11 years $(p=0.001)$ and from those aged 12 years or older $(p=0.003)$. For longterm recall, there were significant differences between the children aged 7-8 years and those aged $9-10$ years $(p=0.015), 10-11$ years $(p<$ $0.001)$ and 12 years or older $(p<0.001)$. The results are shown in 4 groups of age according to their cognitive development ( $7-8$ years, $9-10$ years, 11-12 years, and 13-14 years.). Finally, in long-term recognition, there were differences between the scores obtained by the children aged 7-8 years and by those aged 12 years or older $(p=0.014)$. In all cases, the younger children achieved worse scores in the memory tests and made more mistakes.

Table 3

Mean values of VMT-SP on Short Term Recall, Long Recall and Recognition and its errors for all ages, 7-8, 9-10, 11-12 and 13-14 years old in control and Learning Disability group

\begin{tabular}{|c|c|c|c|c|c|}
\hline Control Group & $\begin{array}{c}\text { All ages } \\
\mathrm{N}=138 \\
\text { Mean (SD) }\end{array}$ & $\begin{array}{c}7-8 \text { years } \\
N=47 \\
\text { Mean (SD) }\end{array}$ & $\begin{array}{c}9 \text { - } 10 \text { years } \\
\mathrm{N}=32 \\
\text { Mean (SD) }\end{array}$ & $\begin{array}{c}11 \text { - } 12 \text { years } \\
\mathrm{N}=35 \\
\text { Mean (SD) }\end{array}$ & $\begin{array}{c}13-14 \text { years } \\
N=24 \\
\text { Mean (SD) }\end{array}$ \\
\hline Short Term Recall & $8(2.41)$ & $6.98(2.35)$ & $7.87(2.03)$ & $8.8(2.55)$ & $9(2.04)$ \\
\hline Errors & $0.12(0.43)$ & $0.15(.42)$ & $0.03(0.18)$ & $0.17(0.57)$ & $0.13(0.44)$ \\
\hline Long Term Recall & $6.21(2.55)$ & $4.83(2.5)$ & $6.5(2.15)$ & $7.18(2.04)$ & $7.21(2.67)$ \\
\hline Errors & $0.18(0.51)$ & $0.15(0.46)$ & $0.22(0.49)$ & $0.15(0.44)$ & $0.25(0.68)$ \\
\hline Recognition & $13.6(3.94)$ & $12.55(4.34)$ & $12.75(3.44)$ & $14.94(3.13)$ & $14.96(3.99)$ \\
\hline Errors & $0.63(1.64)$ & $0.87(1.98)$ & $0.34(0.79)$ & $0.73(2.08)$ & $0.42(0.83)$ \\
\hline LD Group & $\begin{array}{c}\mathrm{N}=187 \\
\text { Mean (SD) }\end{array}$ & $\begin{array}{c}\mathrm{N}=68 \\
\text { Mean (SD) }\end{array}$ & $\begin{array}{c}N=44 \\
\text { Mean (SD) }\end{array}$ & $\begin{array}{c}\mathbf{N}=33 \\
\text { Mean (SD) }\end{array}$ & $\begin{array}{c}\mathbf{N}=\mathbf{4 2} \\
\text { Mean (SD) }\end{array}$ \\
\hline Short Term Recall & $6.27(2.72)$ & $5.68(2.48)$ & $6.34(3.11)$ & $6.67(2.8)$ & $6.86(2.47)$ \\
\hline Errors & $0.28(0.74)$ & $0.18(0.626)$ & $0.37(0.82)$ & $0.18(0.58)$ & $0.45(0.9)$ \\
\hline Long Term Recall & $4.69(2.56)$ & $3.91(2.42)$ & $4.67(2.89)$ & $5.5(2.56)$ & $5.31(2.07)$ \\
\hline Errors & $0.28(0.65)$ & $0.21(0.57)$ & $0.39(0.83)$ & $0.22(0.42)$ & $0.32(0.7)$ \\
\hline Recognition & $10.82(4.76)$ & $10.08(4.86)$ & $10.42(5.41)$ & $10.97(4.18)$ & $12.33(4.05)$ \\
\hline Errors & $1.13(1.77)$ & $1.4(2.32)$ & $1.37(1.63)$ & $0.66(1.15)$ & $0.83(1.18)$ \\
\hline
\end{tabular}

Table 4

ANOVAs of VMT-SP on Short Term Recall, Long

Term Recall and Recognition and its errors by

Group and Age

\begin{tabular}{lrrrrrr}
\hline \multirow{1}{*}{\multicolumn{1}{c}{ Variables }} & \multicolumn{3}{c}{ ANOVA by Group } & \multicolumn{3}{c}{ ANOVA by Age } \\
\cline { 2 - 7 } & \multicolumn{1}{c}{ F } & $\boldsymbol{p}$ & Partial $\boldsymbol{\eta}^{2}$ & \multicolumn{1}{c}{ F } & \multicolumn{1}{c}{$\boldsymbol{p}$} & Partial $^{\mathbf{2}}$ \\
\hline Short Term Recall & 32.79 & $<0.001$ & 0.09 & 6.54 & $<0.001$ & 0.06 \\
Errors & 6.09 & 0.015 & 0.02 & 1.01 & 0.388 & 0.01 \\
Long Term Recall & 27.04 & $<0.001$ & 0.08 & 11.3 & $<0.001$ & 0.10 \\
Errors & 1.91 & 0.168 & 0.01 & 1.08 & 0.356 & 0.01 \\
Recognition & 29.32 & $<0.001$ & 0.09 & 4.56 & 0.004 & 0.04 \\
Errors & 6.42 & 0.012 & 0.02 & 1.60 & 0.189 & 0.01 \\
\hline
\end{tabular}

Objective 2: Relations between the VMT-SP and (a) measures of visual memory and perception and (b) sociodemographic variables

In addition to the VMT-SP test, a previouslyvalidated visual memory test (Rey's complex figure) and Hooper's test of visuospatial organisation were applied. Mann-Whitney tests were performed for independent samples, and significant differences were observed between the $\mathrm{LD}$ and control groups in copying the Rey figure, $U=17.764, z=5.53, p<0.001, d=$ 0.61 , in recalling the Rey figure, $U=16.72, z$ $=4.20, p<0.001, d=0.51$, and in the total number of objects recognised in the Hooper test, $U=14.94, z=2.85, p=0.004, d=0.33$. In all cases, the LD group performed worse than the control group. Bivariate correlation analysis, using Spearman's Rho was carried out of the relationship between the VMT-SP and the other tests evaluating visual aspects (Table 5), both for the LD and the control groups. Significant correlations were obtained between the scores for the three dimensions of the visual memory test and the direct scores, both in copying and in the recall of Rey's complex figure. For the Hooper test, too, there were positive correlations with the number of objects identified in visuospatial processing. 


\section{Table 5}

Relations between the three dimensions of the VMTSP and scores for Rey's complex figure and for Hooper's test for Learning Disability and Control group

\begin{tabular}{|c|c|c|c|c|c|}
\hline & $\begin{array}{c}\text { Long Term } \\
\text { Recall }\end{array}$ & Recognition & Rey's Copy & Rey's Memory & Hoоper \\
\hline Short Term Recall & $0.696 * * / 0.796 * *$ & $0.526 * * / 0.556^{* * *}$ & $0.392^{* *} / 0.292^{* * *}$ & $0.318^{* * / 0.327 * *}$ & $0.386^{* *} / 0.224 * *$ \\
\hline Long Term Recall & & $0.498^{* *} / 0.522^{* *}$ & $0.394 * * / 0.416^{* *}$ & $0.389^{* *} / 0.440^{* *}$ & $0.406^{* *} / 0.279^{* *}$ \\
\hline $\begin{array}{l}\text { Recognition } \\
\text { Rey's Cony }\end{array}$ & & & $0.197 * * / 0.289 * *$ & $0.226^{* *} / 0.352^{* * *}$ & $0.258^{* *} / 0.220^{* *}$ \\
\hline $\begin{array}{l}\text { Rey'sCopy } \\
\text { Rey's Memory }\end{array}$ & & & & $0.760^{* * *} / 0.640^{* * *}$ & $\begin{array}{l}0.505^{5 * *} / 0.392 * * \\
0.423^{* *}\left(0.322^{* *}\right.\end{array}$ \\
\hline
\end{tabular}

Positive correlations were found between age and the scores for the three test dimensions; the older the subject, the higher the score achieved, in short term $(R h o L D=0.240, p=0.001$; Rho $\mathrm{CG}=0.339, p<0.001)$, long term $($ Rho $\mathrm{LD}=$ $0.266, p<0.001$; Rho $\mathrm{CG}=0.396, p<0.001)$, and recognition (Rho $L D=0.196, p=0.008$; Rho $\mathrm{CG}=0.242, p<0.001)$. Regarding gender, in the Mann-Whitney tests, the only variable presenting statistically significant differences was long-term recognition, $U=10.04, z=-2.49 p$ $=0.013, d=0.27$. ANOVAS were performed taking Habitat as the independent variable at three levels (urban, semi-urban and rural). The results were statistically significant for longterm, $F(2.305)=3.64, p=0.027$, partial $\eta^{2}=0.023$. The post-hoc analyses revealed differences between the children from rural areas and those from urban environments, with the former obtaining lower scores than those from urban areas. Finally, no significant relationships were found with respect to the level of education of the mother.

The sociodemographic variables (age, gender, habitat and mother's level of education) were included in the backward linear regressions as independent variables (Table 6). In the first dimension, short-term recall, the final model was statistically significant, F $(6,318)=6.27, p<$ 0.001 , accounting for $11 \%$ of the variance $(R=$ $\left.0.325, R^{2}=0.11\right)$. The significant variables were age, and mother's educational level (see Table 6). In the second dimension, long-term recall, the final regression model was also statistically significant, $F(5,308)=8.44, p<0.001$, accounting for $12 \%$ of the variance $(R=0.347$, $R^{2}=0.12$ ). In this case, the gender variable was eliminated from the model since it was not significant. Finally, with respect to longterm recognition, the final model that included age, gender and mother's level of education (University) was statistically significant, F (5, $\left.311)=9.66 p<0.001, R=0.292, R^{2}=0.08\right)$.

Table 6

Backward linear regression models, including sociodemographic variables, for each of the variables in the VMT-SP

\begin{tabular}{ccrrrrr}
\hline Models & Variables & $\begin{array}{r}\text { Standarized } \\
\text { Beta }\end{array}$ & $\boldsymbol{t}$ & $\boldsymbol{p}$ & $\begin{array}{r}\mathbf{9 5 \%} \text { CI } \\
\text { Inferior }\end{array}$ & $\begin{array}{r}\mathbf{9 5 \%} \text { CI } \\
\text { Superior }\end{array}$ \\
\hline Short Term & Age & 0.251 & 4.70 & $<0.001$ & 0.015 & 0.04 \\
Recall & Gender & 0.097 & 1.81 & 0.070 & -0.045 & 1.12 \\
& Habitat. Rural & -0.092 & -1.71 & 0.089 & -1.29 & 0.09 \\
& MLE. Primary & 0.143 & 2.02 & 0.043 & 0.02 & 1.54 \\
& MLE. Secondary & 0.161 & 2.32 & 0.021 & 0.16 & 1.95 \\
& MLE. University & 0.133 & 2.21 & 0.028 & 0.16 & 2.77 \\
Long Term & Age & 0.29 & 5.41 & $<0.001$ & 0.02 & 0.04 \\
Recall & Habitat. Rural & -0.119 & -2.19 & 0.029 & -1.43 & -0.08 \\
& MLE. Primary & 0.122 & 1.70 & 0.090 & -0.10 & 1.40 \\
& MLE. Secondary & 0.156 & 2.23 & 0.027 & 0.12 & 1.89 \\
& MLE. University & 0.118 & 1.94 & 0.053 & -.02 & 2.53 \\
Recognition & Age & 0.21 & 3.84 & $<0.001$ & 0.02 & 0.05 \\
& Gender & 0.145 & 2.67 & 0.008 & 0.36 & 2.37 \\
& MLE. University & 0.143 & 2.62 & 0.009 & 0.66 & 4.63 \\
\hline & & & & & & \\
\hline
\end{tabular}

NotesMLE $=$ Mother's level of education

\section{Discussion}

The present study had two main aims: (i) to develop a visual memory test based on recognizable objects and to determine their normative values in a population of children with LD and a control group; and (ii) to assess the validity of this test regarding other visual tasks and taking into account certain sociodemographic variables. The main results obtained suggested that short-term, longterm recall and long-term recognition differed significantly between the LD children and the control group. Moreover, the scores were influenced by the age of the children (with a higher percentage of correct answers being given by the older children). Finally, the test results were considered in relation to other tasks of visual memory and visuospatial perception. This article describes a neuropsychological tool for assessing visual memory, using recognizable objects. It provides several advantages: the test is short, handy and stimuli are very familiar for children.

On regards to the sociodemographic variables, child's age, gender, mother's level of education and their environment or habitat was important 
in accounting for the test scores obtained. First, the influence of age may be attributable to the children's natural evolution and growing cognitive maturity, as well as the fact that visual memory is naturally increased by age (Amundsen, Garmannslund, \& Stokke, 2014; Mous et al., 2017; Putzke, Williams, Adams, \& Boll, 1998) thus, in both groups the older the child, the higher the scores obtained. In this line, a recent cross-sectional study performing a complete assessment of neuropsychological domains in children of 7, 9 and 11 years showed differences by age in the vast majority of the tasks (Burneo-Garcés et al., 2019).

In addition, our study highlights the differences between children from urban and rural areas, with lower scores for those children from rural areas. Previous studies have addressed this issue; attributing this phenomenon to individual differences in performance (Santos, Mello, Bueno, \& Dellatolas, 2005). On the other hand, Freire et al. (2010) conducted a study with a sample population similar to ours (children from urban and rural areas in the province of Granada), and concluded that there is a significant association between the type of food consumed, the levels of mercury in it and the cognitive level of the children, especially regarding memory and verbal expression. Other authors attribute the differences to urban life itself, suggesting that the type of cognitive ability needed in the city, such as reading, calculating distances, etc., is different from that needed by children living in rural areas (Stevenson, Chen, \& Booth, 1990).

Regarding the gender differences in visual memory, previous studies indicate that women have better performance in verbal and auditory episodic memory tasks, such as remembering words, objects, pictures or everyday events (Lowe, Mayfield, \& Reynolds, 2003). One possible explanation is that women tend to process visual information in a more integrated manner, (McGivern et al., 1998) surpassing men's performance on visual memory tasks (Robert \& Savoie, 2006; Trahan \& Quintana, 1990), while men have better performance in remembering symbolic and non-linguistic information (Pauls, Petermann, \& Lepach, 2013).

The education level of the mother had also an influence on the scores on the visual memory test. This factor, in sum with parents' occupation and income, is one of the components of socioeconomic status, which is widely associated with children's cognitive development (BurneoGarcés et al., 2019; Muñoz-Vinuesa et al., 2018), having a direct influence on parent-child interactions (Duncan \& Magnuson, 2012). Some studies have found associations between parents' level of education and hippocampal size, an area directly involved in memory processes (Bird \& Burgess, 2008; Noble et al., 2015).

In terms of the relationship between VMTSP and other tests, an interesting finding was the existence of statistically significant positive correlations with other tests of visual memory and visuospatial processing. This suggests that although the diverse tests assess the same general cognitive area, the instrument presented in this paper examines specific aspects of visual memory, associated with the perception of recognizable objects. As observed elsewhere, this type of test may be focused on a different dimension, namely the connection between semantic and episodic memory of objects and words (Wyatt, Conners, \& Carr, 1998).

The results of the present research also have important implications for clinical intervention. Visual memory is a central domain that should be included in neuropsychological interventions programs, especially in those addressed to children diagnosed with learning disabilities (see Correa, Fernández-Alcántara, Pérez-García, Laynez-Rubio, \& Cruz-Quintana, 2017 for a recent example).

Finally, it should be noted that this study has various limitations. Firstly, we present preliminary data concerning the test, and further studies are needed to test the usefulness of this instrument in other clinical populations, and its validity in regards to other visual tests and assessments of executive function. Secondly, the sampling method did not allow generalizing the present results to other populations. Thirdly, given that the initial validation was performed 
exclusively in the province of Granada, Spain; in urban areas with a larger population, the results obtained might be different.

In conclusion, the Visual Memory Test based on Snodgrass Pictures (VMT-SP) is a new clinical tool for assessing visual memory in children. Evidence of its concurrent validity and applicability in the evaluation of children with LD is presented.

\section{Acknowledgements}

This research was supported by the Health Research Project titled "Neuropsychological markers in children with learning disabilities" [Estudio de indicadores neuropsicológicos en niños con problemas del aprendizaje] (Ref: PI-10/02735), Principal Investigator: Carolina Laynez Rubio. MFA is funded by Conselleria d'Educació, Investigació, Cultura i Esport de la Generalitat Valenciana (Proyectos I+D + I desarrollados por grupos de investigación emergentes) [GV/2017/166].

\section{References}

Alloway, T. P., Banner, G. E., \& Smith, P. (2010). Working memory and cognitive styles in adolescents' attainment. British Journal of Educational Psychology, 80(4), 567-581.

Achenbach, T. M., \& Rescorla, L. (2001). ASEBA school-age forms $\mathbb{E}$ profiles. Burlington: Aseba.

Amundsen, M. L., Garmannslund, P. E., \& Stokke, H. (2014). Visual working memory - Gender and age differences. European Journal of Educational Sciences, 1(3), 1-17. Retrieved from http://ejes.eu/wp-content/u ploads/2016/01/1-3-1.pdf

Bain, S. K., \& Jaspers, K. E. (2010). Test Review: Review of Kaufman Brief Intelligence Test: Kaufman, AS, \& Kaufman, NL (2004). Kaufman Brief Intelligence Test, Second Edition. Bloomington, MN: Pearson, Inc. Journal of Psychoeducational assessment, 28(2), 167-174. https://doi.org/10.1177/07 34282909348217
Bird, C. M., \& Burgess, N. (2008). The hippocampus and memory: insights from spatial processing. Nature Reviews Neuroscience, 9(3), 182-194. https://doi.org $/ 10.1038 / \mathrm{nrn} 2335$

Brandenburg, J., Klesczewski, J., Fischbach, A., Schuchardt, K., Büttner, G., \& Hasselhorn, M. (2015). Working memory in children with learning disabilities in reading versus spelling: Searching for overlapping and specific cognitive factors. Journal of learning disabilities, 48(6), 622-634. https://doi.org/1 $0.1177 / 0022219414521665$

Brankaer, C., Ghesquiere, P., \& De Smedt, B. (2014). Numerical magnitude processing deficits in children with mathematical difficulties are independent of intelligence. Research in Developmental Disabilities, 35(11), 2603-26261. https://doi.org/10.101 6/j.ridd.2014.06.022

Brown, F. C., Roth, R. M., Saykin, A. J., \& Beverly-Gibson, G. (2007). A new measure of visual location learning and memory: development and psychometric properties for the Brown Location Test (BLT). The Clinical Neuropsychologist, 21(5), 811-825. https://doi.org/10.1080/13 854040600878777

Bull, R., Espy, K. A., \& Wiebe, S. A. (2008). Short-term memory, working memory, and executive functioning in preschoolers: Longitudinal predictors of mathematical achievement at age 7 years. Developmental Neuropsychology, 33(3), 205-228. https://do i.org/10.1080/87565640801982312

Burneo-Garcés, C., Cruz-Quintana, F., PérezGarcía, M., Fernández-Alcántara, M., Fasfous, A., \& Pérez-Marfil, M. N. (2019). Interaction between Socioeconomic Status and Cognitive Development in Children Aged 7, 9, and 11 Years: A Cross-Sectional Study. Developmental Neuropsychology, 44(1), 1-16. https://doi.org/10.1080/87565 641.2018 .1554662

Carlisle, N. B. \& Kristjánsson, Á. (2018). How visual working memory contents influence priming of visual attention. Psychological 
Research, 82(5), 833-839. https://doi.org/10 $.1007 / \mathrm{s} 00426-017-0866-6$

Chun, M. M. (2011). Visual working memory as visual attention sustained internally over time. Neuropsychologia, 49(6), 1407-1409. https://doi.org/10.1016/j .neuropsychologia.2011.01.029

Correa, C., Fernández-Alcántara, M., PérezGarcía, M., Laynez-Rubio, C., \& CruzQuintana, F. (2017). Effects of an Executive Functions stimulation programme for children with learning disabilities/Efectos de un programa de estimulación de las Funciones Ejecutivas en niños con dificultades de aprendizaje. Estudios de Psicología, 38(2), 537-551. https://doi.org/1 $0.1080 / 02109395.2017 .1295576$

Corsi, P. M. (1973). Human memory and the medial temporal region of the brain (Unpublished doctoral dissertation). McGill University. Montreal. Retrieved from http://digitool.library.mcgill.ca/webcli ent/StreamGate?folder_id=0\&dvs=15589 $16387370 \sim 169$

Duncan, G. J., \& Magnuson, K. (2012). Socioeconomic status and cognitive functioning: moving from correlation to causation. Wiley Interdisciplinary Reviews: Cognitive Science, 3(3), 377-386. https://doi .org/10.1002/wcs. 1176

Cuetos, F., Ellis, A. W., \& Alvarez, B. (1999). Naming times for the Snodgrass and Vanderwart pictures in Spanish. Behavior Research Methods, Instruments, $\mathbb{E}$ Computers, 31 (4), 650-658. https://doi.org/ 10.3758/BF03200741

Eng, H. Y., Chen, D., \& Jiang, Y. (2005). Visual working memory for simple and complex visual stimuli. Psychonomic Bulletin Ë Review, 12 (6), 1127-1133. https://doi.org /10.3758/BF03206454

Franconeri, S. L., Alvarez, G. A., \& Cavanagh, P. (2013). Flexible cognitive resources: competitive content maps for attention and memory. Trends in cognitive sciences, 17(3), 134-141. https://doi.org/10.1016/j.tics.201 3.01 .010
Freire, C., Ramos, R., Lopez-Espinosa, M.J., Díez, S., Vioque, J., Ballester, F., \& Fernández, M.-F. (2010). Hair mercury levels, fish consumption, and cognitive development in preschool children from Granada, Spain. Environmental Research, 110(1), 96-104. https://doi.org/10.1016/j.e nvres.2009.10.005

Garcia, R. B., Mammarella, I. C., Tripodi, D., \& Cornoldi, C. (2014). Visuospatial working memory for locations, colours, and binding in typically developing children and in children with dyslexia and nonverbal learning disability. British Journal of Developmental Psychology, 32(1), 17-33. htt ps://doi.org/10.1111/bjdp.12019

Garcia, R. B., Mammarella, I. C., Pancera, A., Galera, C., \& Cornoldi, C. (2015). Deficits in visual short-term memory binding in children at risk of nonverbal learning disabilities. Research in developmental disabilities, 45-46, 365-372. h ttps://doi.org/10.1016/j.ridd.2015.07.035

Hooper, E. H. (1983). Hooper visual organization test (VOT). Los Angeles, LA: Western Psychological Services.

Kaufman, A. S., \& Kaufman, N. L. (2004). Kaufman brief intelligence test. John Wiley \& Sons, Inc.

Klesczewski, J., Brandenburg, J., Fischbach, A., Grube, D., Hasselhorn, M., \& Büttner, G. (2015). Working memory functioning in children with poor mathematical skills. Zeitschrift für Psychologie, 233, 83-92. https: //doi.org/10.1027/2151-2604/a000206

Liebel, S. W., \& Nelson, J. M. (2017). Auditory and Visual Working memory functioning in college students with attentiondeficit/hyperactivity disorder and/or Learning Disabilities. Archives of Clinical Neuropsychology, 32 (8), 980-991. https://do i.org/10.1093/arclin/acx014

Lowe, P. A., Mayfield, J. W., \& Reynolds, C. R. (2003). Gender differences in memory test performance among children and adolescents. Archives of Clinical Neuropsychology, 18(8), 865-878. https://do i.org/10.1016/S0887-6177(02)00162-2 
Visual Memory Test based on Snodgrass Pictures (VMT-SP): a New Neuropsychological Measure of...

Luck, S. J., \& Hollingworth, A. R. (2008). Visual memory. New York, NY: University Press.

Maehler, C., \& Schuchardt, K. (2016). The importance of working memory for school achievement in primary school children with intellectual or learning disabilities. Research in developmental disabilities, 58, 1-8. https://doi.org/10.1016/j.ridd.2016.08.007

Mammarella, I. C., \& Pazzaglia, F. (2010). Visual perception and memory impairments in children at risk of nonverbal learning disabilities. Child Neuropsychology, 16(6), 564-576. https://doi.org/10.1080/09297049 .2010 .485125

Mammarella, I. C., Giofrè, D., Ferrara, R., \& Cornoldi, C. (2013). Intuitive geometry and visuospatial working memory in children showing symptoms of nonverbal learning disabilities. Child Neuropsychology, 19(3), 235-249. https://doi.org/10.1080/09 297049.2011.640931

McGivern, R. F., Mutter, K. L., Anderson, J., Wideman, G., Bodnar, M., \& Huston, P. J. (1998). Gender differences in incidental learning and visual recognition memory: support for a sex difference in unconscious environmental awareness. Personality and Individual Differences, 25(2), 223-232. https://doi.org/10.1016/S0191-88 69(98)00017-8

Montgomery, J. W. (2000). Verbal working memory and sentence comprehension in children with specific language impairment. Journal of Speech, Language, and Hearing Research, 43(2), 293-308. https://doi.org/10 $.1044 /$ jslhr.4302.293

Mous, S. E., Schoemaker, N. K., Blanken, L. M., Thijssen, S., van der Ende, J., Polderman, T. J., ... White, T. (2017). The association of gender, age, and intelligence with neuropsychological functioning in young typically developing children: The generation R study. Applied Neuropsychology: Child, 6(1), 22-40. https:/ /doi.org/10.1080/21622965.2015.1067214

Müller, B. W., Gimbel, K., Keller-Pließnig, A., Sartory, G., Gastpar, M., \& Davids, E. (2007). Neuropsychological assessment of adult patients with attention-deficit/ hyperactivity disorder. European Archives of Psychiatry and Clinical Neuroscience, 257(2), 112-119. https://doi.org/10.1007/s00406-0 06-0688-9

Muñoz-Vinuesa, A., Afonso-Martín, A., Cruz-Quintana, F., Pérez-Marfil, M. N., Sotomayor-Morales, E. M., \& Fernández-Alcántara, M. (2018). Determinantes sociales de la salud. Estatus socioeconómico, neurodesarrollo y funciones ejecutivas en la infancia. Index Enfermería, 27, 143-146. Retrieved from https://rua.ua.es/dspace/bitstream/10 045/85571/1/2018_Munoz-Vinuesa_etal_I ndexEnferm.pdf

Narimoto, T., Matsuura, N., Takezawa, T., Mitsuhashi, Y., \& Hiratani, M. (2013). Spatial short-term memory in children with nonverbal learning disabilities: Impairment in encoding spatial configuration. The Journal of genetic psychology, 174(1), 73-87. https://doi.org/10.1080/00221325.2 011.641040

Noble, K. G., Houston, S. M., Brito, N. H., Bartsch, H., Kan, E., Kuperman, J. M., ... \& Schork, N. J. (2015). Family income, parental education and brain structure in children and adolescents. Nature neuroscience, 18(5), 773. https://doi. org/10.1038/nn.3983

Passolunghi, M. C. (2006). Working memory and mathematical disability. In T. Packiam Alloway \& S. Gathercole (Eds.), Working memory and neurodevelopmental condition (pp. 113-138). Hove, UK: Psychology Press

Pauls, F., Petermann, F., \& Lepach, A. C. (2013). Gender differences in episodic memory and visual working memory including the effects of age. Memory, 21 (7), 857-874. http s://doi.org/10.1080/09658211.2013.765892

Pérez, M. A. \& Navalón, C. (2003). Normas españolas de 290 nuevos dibujos: Acuerdo en la denominación, concordancia de la imagen, familiaridad, complejidad visual y variabilidad de la imagen. Psicológica: Revista de Metodología y Psicología Learning Disability, 24(2), 215-242. 
Peterson, D. J., \& Berryhill, M. E. (2013). The Gestalt principle of similarity benefits visual working memory. Psychonomic bulletin $\mathfrak{E}$ review, 20 (6), 1282-1289. https://doi.org/10 $.3758 / \mathrm{s} 13423-013-0460-\mathrm{x}$

Pissella, L., \& Mattingley, J. B. (2004). The contribution of spatial remapping impairments to unilateral visual neglect. Neuroscience $\mathbb{E}$ Biobehavioral Reviews, 28(2), 181-200. https://doi.org/10.1016/j.n eubiorev.2004.03.003

Price, J. P. (2009). The computerized object and abstract designs test (COAD): A pilot study of a new test of visual working memory. British Journal of Clinical Psychology, 48(2), 109-123. https://doi.org/10.1348/01446650 $8 \times 366713$

Putzke, J. D., Williams, M. A., Adams, W., \& Boll, T. J. (1998). Does memory test performance in children become more consistent with age? Cross-sectional comparisons using the WRAML. Journal of Clinical and Learning Disability Neuropsychology, 20(6), 835-845. Retrieved from https://eurekamag.com/rese $\operatorname{arch} / 010 / 491 / 010491425 . p h p$

Reales, J. M., Ballesteros, S., \& García, E. (2002). Visual-word identification thresholds for the 260 fragmented words of the Snodgrass and Vanderwart pictures in Spanish. Behavior Research Methods, Instruments, $\mathcal{E}$ Computers, 34(2), 276-285. https://doi.org/ 10.3758/BF03195455

Rey, A. (1980). REY. Test de Copia de una Figura Compleja. Madrid: Tea Ediciones

Rhodes, S. M., Coghill, D. R., \& Matthews, K. (2004). Methylphenidate restores visual memory, but not working memory function in attention deficit-hyperkinetic disorder. Psychopharmacology, 175(3), 319-330. https ://doi.org/10.1007/s00213-004-1833-7

Robert, M., \& Savoie, N. (2006). Are there gender differences in verbal and visuospatial working-memory resources? European Journal of Cognitive Psychology, 18(3), 378-397. https://doi.org/10.1080/09 541440500234104

Santos, F. H., Mello, C. B., Bueno, O. F. A., \& Dellatolas, G. (2005). Cross-cultural differences for three visual memory tasks in Brazilian children. Perceptual and Motor Skills, 101 (2), 421-433. https://doi.org/10.2 466/pms.101.2.421-433

Schuchardt, K., \& Mähler, C. (2016). Exekutive Funktionen bei Kindern mit Lernstörungen. Praxis der Kinderpsychologie und Kinderpsychiatrie, 65 (6), 389-405. https ://doi.org/10.13109/prkk.2016.65.6.389

Seigneuric, A., Ehrlich, M.-F., Oakhill, J. V., \& Yuill, N. M. (2000). Working memory resources and children's reading comprehension. Reading and Writing, 13(1-2), 81-103. https://doi.org/10.1023/A :1008088230941

Semrud-Clikeman, M., Walkowiak, J., Wilkinson, A., \& Butcher, B. (2010). Executive functioning in children with Asperger syndrome, ADHD-combined type, ADHD-predominantly inattentive type, and controls. Journal of Autism and Developmental Disorders, 40(8), 1017-1027. https://doi.org/10.1016/j.sbspro .2014 .04 .281

Shang, C. Y., \& Gau, S. S. (2011). Visual memory as a potential cognitive endophenotype of attention deficit hyperactivity disorder. Psychological Medicine, 41(12), 2603-2614. http://dx.doi.org/10.1017/S003 3291711000857

Snodgrass, J. G., \& Vanderwart, M. (1980). A standardized set of 260 pictures: norms for name agreement, image agreement, familiarity, and visual complexity. Journal of Learning Disability Psychology: Human Learning and Memory, 6(2), 174. Retrieved from https://slab.lscore.ucla.edu/MIT/MIT _Papers/PMIT\%20260\%20Snodgrass\%201 980.pdf

Soprano, A. M. (2003). Evaluación de las funciones ejecutivas en el niño. Revista de Neurología, 37(1), 44-50. https://doi.org/10 .33588/rn.3701.2003237

Souza, A. S., \& Oberauer, K. (2017). The contributions of visual and central attention to visual working memory. Attention, Perception, Eु Psychophysics, 
79(7), 1897-1916. https://doi.org/10.3758/s 13414-017-1357-y

Stadthagen-González, H., Damian, M. F., Pérez, M. A., Bowers, J. S., \& Marín, J. (2009). Name-picture verification as a control measure for object naming: A task analysis and norms for a large set of pictures. The Quarterly Joumal of Learning Disability Psychology, 62 (8), 1581-1597. https://doi.or g/10.1080/17470210802511139

Stevenson, H. W., Chen, C., \& Booth, J. (1990). Influences of schooling and urban-rural residence on gender differences in cognitive abilities and academic achievement. Sex Roles, 23(9-10), 535-551. https://doi.org/10 $.1007 / \mathrm{BF} 00289767$

Tirado-Durán, E. (2006). Evaluación neuropsicológica y neurocirugía psiquiátrica. Salud Mental, 29, 13-17. Retrieved from: https://www.medigraphic.c om/cgi-bin/new/resumen.cgi?IDARTICUL $\mathrm{O}=13932$

Trahan, D. E., \& Quintana, J. W. (1990). Analysis of gender effects upon verbal and visual memory performance in adults. Archives of Clinical Neuropsychology, 5(4), 325-334. https://doi.org/10.1016/0887-617 $7(90) 90012-\mathrm{E}$

Wang, L., Chen, C.W., \& Zhu, L. (2014). Picture norms for Chinese preschool children: Name agreement, familiarity, and visual complexity. PloS One, 9(3), e90450. https:/ /doi.org/10.1371/journal.pone.0090450

Werpup-Stuewe, L., \& Petermann, F. (2015). Visual perception abilities in children with reading disabilities. Zeitschrift fur Kinder-und Jugendpsychiatrie und Psychotherapie, 43(3), 195-205. https://doi.org/10.1024/1422-491 7/a000353

Willis, S., Goldbart, J., \& Stansfield, J. (2014). The strengths and weaknesses in verbal short-term memory and visual working memory in children with hearing impairment and additional language learning difficulties. International Journal of Pediatric Otorhinolaryngology, 78(7), 1107-1114. https://doi.org/10.1016/j.ijporl. 2014.04 .025
Wyatt, B. S., Conners, F. A., \& Carr, M. D. (1998). The Snodgrass picture fragment completion test: Alternate-form reliability. Behavior Research Methods, Instruments, $\mathcal{E}^{2}$ Computers, 30(2), 360-368.

\section{Notes}

* Research article. 